Науковий вісник НЛТУ України

Scientific Bulletin of UNFU

http://nv.nltu.edu.ua

https://doi.org/10.15421/40270809

Article received 6.11.2017 p.

Article accepted 24.11.2017 p.
ISSN 1994-7836 (print)

ISSN 2519-2477 (online)

@ Correspondence author

S. I. Myklush

msi_s@ukr.net

UDC $630 * 5$

S. I. Myklush', Yu. S. Myklush', V. M. Savchyn'

${ }^{1}$ Ukrainian National Forestry University, Lviv, Ukraine ${ }^{2}$ Production Association "Ukrderglisproekt", Lviv, Ukraine

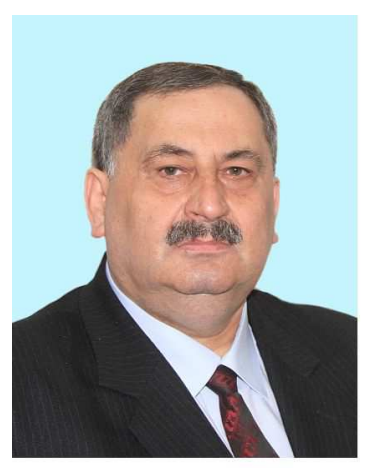

Stepan Myklush,

Dr. Hab., Professor, Email: msi_s@ukr.net

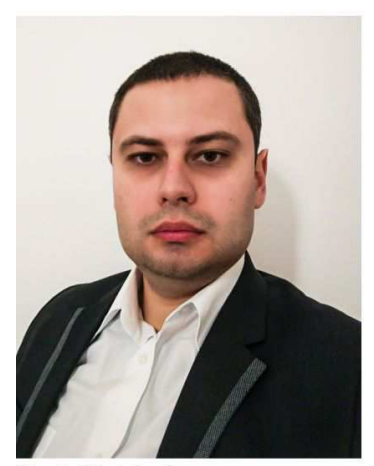

Yurij Myklush,

$\mathrm{PhD}$, Senior Lecturer,

Email:y.myklush@nltu.edu.ua

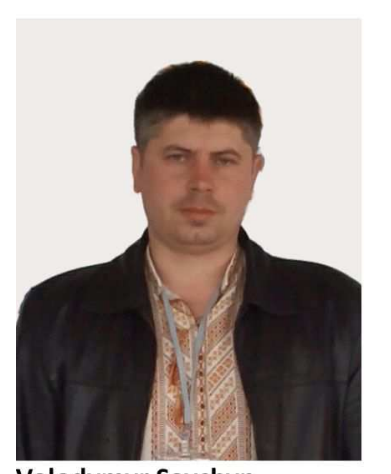

Volodymyr Savchyn,

Chief Technologist of the Lviv State Forestry Expedition, Email: svm_25@ukr.net

\title{
STRUCTURE OF THE FOREST FUND AND FUNCTIONS OF BEECH FORESTS ON UKRAINIAN PLAINS
}

Based on the forest inventory materials, silvicultural and inventory indices of beech stands on the plains of Ukraine as of 01.01.2015 and main functions that are performed by these stands were analyzed. Forest area with beech participation in composition is equal 216113,4 hectares (total number of plots 47231 pieces), and forests with beech prevailing in composition equals 118902,9 hectares (as of $01.01 .1996-104,8$ thousand hectares). It was found that natural seed forest stands prevail in lowland conditions. Forest stands with the participation of beech are formed mainly in fresh (more than $44 \%$ ) and moist (39.4\%) soil types. Pure beech forest stands grow on $8.6 \%$ of the area. Considering covered area middle-aged (occupying $36.9 \%$ ) and mature forest stands (occupying $27.1 \%$ ) are dominating. Seed beech forest stands of both natural and planted origin are characterized by the same middle site class - Ia, 5 and more than $36 \%$ of beech forest stands, regardless of origin, are characterized by a relative completeness of 0.7 . More than $51 \%$ of the areas of plain beech stands belong to protective, recreational and health improving forests and forests of nature conservation, scientific, forests of historical and cultural purposes. Among the recreational and health improving forests, the largest share of the area belongs to the management area of the green zones of settlements - 20.7 thousand hectares, of which almost $14.6 \%$ are represented by natural seed forests. More than 3 thousand hectares $(2.8 \%)$ of beech forests are attributed to the woodland part of the forests of green zones. It is pointed out that intensive forestry activities in middleaged and mature forest stands significantly reduce their relative density and growing stock. Sixteen categories of protectiveness were singled out taking into consideration functions that are predominantly performed by a stand. Transition to a selection system of forest management is proposed in order to ensure formation of highly productive beech forest stands and efficient use of forest resources.

Keywords: silvicultural productions; sowing quality of seeds; forest-seed zoning; forest-typological arguments in favour of forest-seed raw materials harvesting; silvicultural zoning.

\section{Introduction}

Forests of Ukraine are formed by more than 30 woody species with predominance of common pine (Pinus silvestris L.), European oak (Quercus robur L.), European beech ( $\mathrm{Fa}$ gus silvatica L.), Norway spruce (Picea Abies (L.) karst.). European beech stands occupy $7 \%$ of the area covered with forest vegetation (State, 2015). The current distribution of forests in Ukraine, in particular beech forests, is certainly a result of the influence of climatic, geological and soil factors, but primarily anthropogenic ones.

Forests are one of the important factors of ecosystem stabilization, creation of a fa- vorable natural environment (climate change mitigation, production of oxygen, absorption of greenhouse gases, etc.) for people to live, providing conditions for human vital activity, recreation, restoring physical strength and psychoemotional state. Of great importance is the forest as a protective, conservational, and resource factor.

\section{Objects and methods of study}

In view of the significant geographical distribution of forest stands with the involvement of beech species in the flat part of Ukraine, the research was carried out on the basis of the materials from the subcompartment database of the Forest Fund of Ukraine which contains detailed forestinventory characteristics of stands, also used were the materials of literary sources on description of beech forests by different researchers.

The object of studies are stands with participation of European beech as well as beech forests on the plains of Ukraine that grow in Vinnytsia-, Volyn-, Zhytomyr-, Zakarpattia-, Ivano-Frankivsk-, Kyiv-, Lviv-, Rivne-, Sumy-, Ternopil-, Kharkiv-, Khmelnytsky-, Cherkasy- and Cher-

Цитування за ДСТУ: Myklush S. I., Myklush Yu. S., Savchyn V. M. Structure of the forest fund and functions of beech forests on Ukrainian plains. Науковий вісник НЛтУ України. 2017. Вип. 27(8). С. 64-69.

Citation APA: Myklush, S. I., Myklush, Yu. S., \& Savchyn, V. M. (2017). Structure of the forest fund and functions of beech forests on Ukrainian plains. Scientific Bulletin of UNFU, 27(8), 64-69. https://doi.org/10.15421/40270809 
nivtsi regions. The research covers natural and artificial, primary and secondary beech stands growing at the eastern boundary of the natural distribution of European beech, as well as forest outliers.

To analyze forest stand functions, we used the classification of beech forest functions according to the scheme proposed by S. I. Myklush (Myklush, 2011).

\section{Results of the studies}

According to the Forest Fund inventory data as of 1 January 2015 (Directory, 2016), the area of lowland beech-involved stands is 216113.4 hectares (the total number of sites being 47231), and the area of stands with beech predominance in the composition is 118902.9 hectares (as of 1 January $1996-104.8$ thousand hectares). Natural seed stands are predominant among beech forest stands, their share reaching $85.7 \%$; the share of artificially created stands with participation of beech is $17.2 \%$, and with the prevalence of beech $-13.9 \%$. The area of natural stands, where beech predominates in the composition, is almost 102 thousand hectares, while the area of artificially created stands with predominance of beech is over 16.5 thousand hectares. Compared with the inventory data as of 1 January 1996, the year 2015 saw an increase in the area occupied by beech stands. Thus, the area of beech forest plantations increased by more than 8 thousand hectares, and the area of natural seed beech forests - by more than 5 thousand hectares.

European beech is one of the main site type-forming species in Ukraine. According to P. I. Molotkov (Molotkov, 1972), about $90 \%$ of all beech forests are concentrated in rich fertile forest-site types. The beech in the study region is distributed in fresh, moist and wet hygrotopes and, as a rule, in fairly fertile and fertile trophotopes.

Forest stands with the participation of European beech are formed mainly in fresh (more than $44 \%$ ) and moist $(39.4 \%)$ fertile site types. Natural seed stands with the participation of beech cover more than two-thirds $(68.3 \%)$ of the area of fresh and moist fertile site types, forest plantation prevailing in these conditions over an area of more than $14 \%$, and vegetative stands cover an area of less than $0.4 \%$.

In natural seed forest stands, there is a relatively even area distribution of forest stands with a different proportion of beech in composition. Thus, the share of the area varies from $7 \%$ (stands with 9 units in composition: 1 unit=10\%) to $12.6 \%$ in the stands with one unit of beech in the composition (Figure 1).

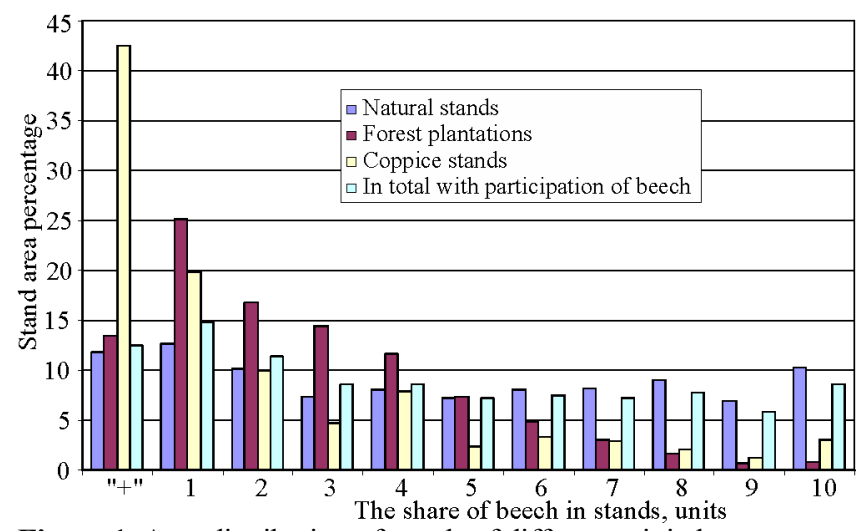

Figure 1. Area distribution of stands of different origin by proportion of beech in composition

Pure forest plantations with the participation of beech occupy $3 \%$ of the area of artificially created plantations.
Prevailing are beech forest plantations with the participation of 1-5 units of beech in the stand's composition. Among coppice stands, prevailing (also by area) are stands with 12 units of beech in the stand's composition.

Pure beech forest stands cover $8.6 \%$ of the area of the lowland beech stands. Most of them (10.3\%) are of natural origin from seed. Among the studied forest stands, almost $12.5 \%$ of them occupy plots where single beech trees occur with a stock of less than $5 \%$ of the stand's volume.

It should be noted that an increase is observed in the proportion of beech in the composition of stands as they grow older, regardless of origin. However, the most significant increase in the proportion of beech in the stands' composition is observed in natural seed stands, where, at the age of 10 , predominant are stands with 3 units of beech, and its share grows up to 8 units at the age of 100 years. Forest plantations involving beech were created in fertile oak forest types and fairly fertile oak forest types, therefore, the proportion of beech in these types of forest usually does not exceed 4 units in the forest stand's composition. In seed beech forests, with the growth of age, sometimes pure beech forests are formed, which is not recorded for coppice forests.

The share of beech in the stands' composition affects their total stocking. Since the European beech grows in different types of site conditions combined with numerous species, from this point on, we will analyze beech forest stands of the working circles (beech forest stands of which consist mainly of 4 (more rarely 3 or 2) units of beech.

European beech grows as a constituent part of stands in 46 types of forest of the flat part of Ukraine and forms 16 forest types. Large areas of beech stands are formed in fresh $(34.8 \%$ of the area) and moist $(26.8 \%)$ oak-hornbeam fertile beech forest types. The smallest area of forest stands with the participation of beech is occupied by forest crops in the fresh lime-pine fairly fertile oak forest type and fresh maple-lime fertile oak forest type in Sumy- and Kharkiv regions.

Area distribution of the lowland beech stands by age groups is nonuniform, it has its own peculiarities depending on the stand's origin (Table 1).

Table 1. Area distribution in lowland beech stands by age groups

\begin{tabular}{|c|c|c|c|c|c|}
\hline \multirow[b]{2}{*}{ Total, ha } & \multicolumn{5}{|c|}{ Including, by age groups } \\
\hline & $\begin{array}{l}\text { Young } \\
\text { growth }\end{array}$ & $\begin{array}{l}\text { Middle- } \\
\text { aged }\end{array}$ & Maturing & Mature & $\begin{array}{l}\text { Old- } \\
\text { growth }\end{array}$ \\
\hline \multicolumn{6}{|c|}{ Natural seed stands } \\
\hline 101882,2 & 6976,0 & 36936,6 & 31198,4 & 25692,5 & 1078,7 \\
\hline \multicolumn{6}{|c|}{ Forest plantations } \\
\hline 16545,5 & 8679,0 & 6680,8 & 857,4 & 297,3 & 31,0 \\
\hline \multicolumn{6}{|c|}{ Stands of vegetative origin } \\
\hline 475,5 & 8,0 & 256,6 & 140,4 & 70,5 & - \\
\hline
\end{tabular}

Among the beech stands of the plains, dominant by area are the middle-aged stands - 36.9\% and maturing$27.1 \%$. In natural forest stands, young growth occupies a small area $(6.8 \%)$, while young growth predominates in artificial stands (52.5\%), although this young growth occupies an area that is only 1.7 thousand hectares larger than that of natural forests. A decrease in the area of coppice stands, in particular young stands, indicates a gradual transition of forest enterprises to growing productive seedling forest stands, that is the use of natural seed regeneration. Beech forest stands of the plains are characterized by a significant area occupied by mature stands $(21.9 \%)$ which, like old- 
growth stands, grow in recreation forests, nature reserves, national parks.

More than $85 \%$ of the land occupied by beech stands are characterized by site classes $\mathrm{I}$ and $\mathrm{II}^{\mathrm{a}}$ according to $\mathrm{M}$. M. Orlov (Figure 2). Seed stands (of seedling origin), depending on the forest site conditions, silvicultural treatments, interactions of forest-forming species, are characterized predominantly by the $\mathrm{I}^{\mathrm{b}}$... III site classes, while the vegetative beech forests grow at site classes I-III. Several areas of natural beech stands of poor site conditions are characterized by site class IV. Regardless of the stand's origin, the largest share (over $45 \%$ ) of the beech stand area is characterized by site class I. In large areas, the beech stands are characterized by site class $\mathrm{I}^{\mathrm{a}}$, most part of this area being occupied by seed stands $-41 \%$. In almost $7 \%$ of the area, seed beech stands are characterized by site class $\mathrm{I}^{\mathrm{b}}$, mainly these are young and middle-aged stands with the participation of conifers, in particular European larch.

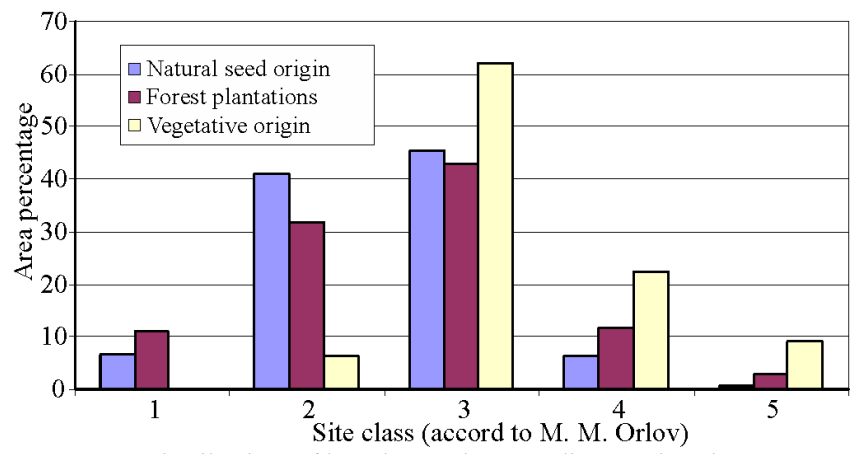

Figure 2. Distribution of beech stands according to site classes

Seed beech stands, both of natural and artificial origin, are characterized by the same average site class $-1^{\mathrm{a}}, 5$, which indicates their high productivity.
The pattern of area distribution in the lowland beech forest stands of different origin according to their relative density indicates a significant prevalence of medium-stocked stands (with relative density of 0.7 ) and a small proportion of fully-stocked forest stands (Figure 3). Thus, more than $36 \%$ of the area of beech forest stands, regardless of their origin, is characterized by a relative density of 0.7 , over $75 \%$ of the area is characterized by relative density of $0.6-0.8$ and more than $60 \%$ of the area - by relative density of $0.7-0.8$. Almost $12 \%$ of the area is characterized by relative density of $0.3-0.5$, and $11 \%$ of the area of beech stands is fully-stocked. The relative density of $0.9-1.0$ is characteristic of over 10 thousand hectares of natural seed forests and almost 2.7 thousand hectares of beech forest plantations. High relative density is characteristic of young- and middle-aged beech forest stands. Forest stands with a relative density of 1.0 grow on 202 sites, of which more than 730 ha (87 sites) are natural stands of seedling origin.

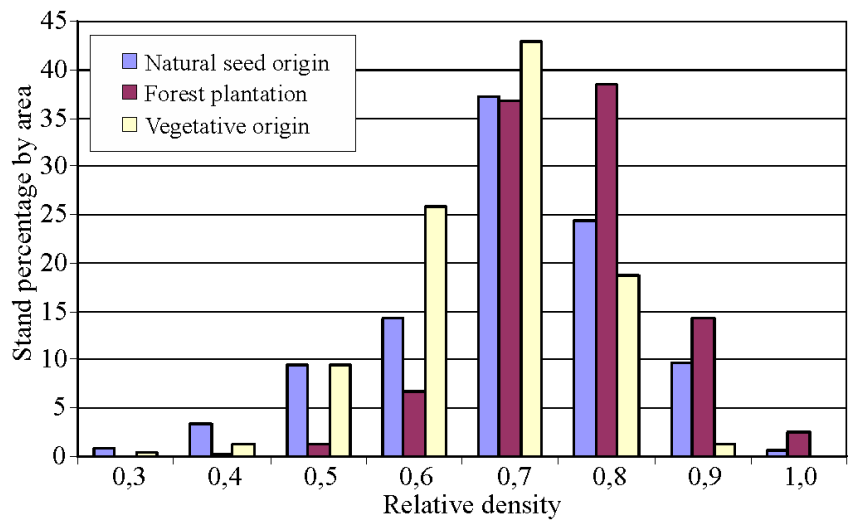

Figure 3. Area distribution in beech stands of different origin by relative density

Table 2. Area distribution in lowland beech forests based on the predominance of functions performed by them

\begin{tabular}{|c|c|c|c|c|c|}
\hline \multirow{2}{*}{$\begin{array}{l}\text { Categories by } \\
\text { predominance of } \\
\text { performed functions }\end{array}$} & \multirow[b]{2}{*}{ Category of protectiveness } & \multirow[b]{2}{*}{ Main functions } & \multicolumn{3}{|c|}{ Area of stand by origin, ha } \\
\hline & & & $\begin{array}{l}\text { natural } \\
\text { seeding }\end{array}$ & $\begin{array}{l}\text { artificial } \\
\text { seeding }\end{array}$ & coppice \\
\hline \multirow{5}{*}{ Protective forests } & ravine forests & protective & 183.7 & 214.5 & \\
\hline & anti-erosion forests & soil-protective & 134.3 & 3.7 & 8.6 \\
\hline & riparian forests & water-protective & $1,216.3$ & 87.8 & \\
\hline & forests of easement area of highways & road-protective & 417.2 & 51.1 & 1.9 \\
\hline & railroad precinct forests & railroad-protective & 139.0 & 64.4 & \\
\hline Total & & & $2,090.5$ & 421.5 & 10.5 \\
\hline \multirow{4}{*}{ Recreation forests } & urban forests & $\begin{array}{c}\text { recreational, } \\
\text { sanitary and hygienic } \\
\end{array}$ & 929.3 & 44.1 & 19.0 \\
\hline & forestry part of forests of green zones & $\begin{array}{c}\text { recreational, } \\
\text { sanitary and hygienic }\end{array}$ & $17,323.8$ & 3277.3 & 106.7 \\
\hline & forest-park part of forests of green zones & $\begin{array}{c}\text { recreational, } \\
\text { sanitary and hygienic }\end{array}$ & $2,822.7$ & 552.5 & 3.8 \\
\hline & $\begin{array}{c}\text { forests of protective zones } 1,2 \text { and } 3,0 \text { of } \\
\text { health-improving establishments }\end{array}$ & $\begin{array}{c}\text { recreational, sanitary and } \\
\text { hygienic, protective }\end{array}$ & 121.1 & 32.3 & \\
\hline Total & & & $21,075.8$ & $3,873.9$ & 129.5 \\
\hline \multirow{8}{*}{$\begin{array}{l}\text { Forests of nature conser- } \\
\text { vation, scientific, histori- } \\
\text { cal and cultural purposes }\end{array}$} & forests of scientific purpose & Cognitive & 725.0 & 24.0 & \\
\hline & forests of historical and cultural purposes & preserving, cognitive & 3.1 & & \\
\hline & reserved forest isolated terrain feature & preserving, research & 970.6 & 50.1 & 5.6 \\
\hline & national natural parks & $\begin{array}{c}\text { cognitive, preserving, } \\
\text { educational }\end{array}$ & $7,645.9$ & $1,737.0$ & 14.2 \\
\hline & natural monuments & cognitive & 852.1 & 80.6 & \\
\hline & natural reserves & preserving & 14.1 & 204.6 & \\
\hline & landscape regional parks & preserving, cognitive & $12,354.4$ & 278.1 & 24.6 \\
\hline & reserved forests & $\begin{array}{l}\text { preserving, cognitive, } \\
\text { research }\end{array}$ & $7,252.7$ & 813.1 & 11.3 \\
\hline Total & & & $29,817.9$ & $3,187.5$ & 55.7 \\
\hline Exploitable forests & exploitable & $\begin{array}{l}\text { protective, raw material } \\
\text { supply }\end{array}$ & $48,776.9$ & $9,030.3$ & 279.8 \\
\hline Total & & & $101,882.2$ & $16,545.5$ & 475.5 \\
\hline
\end{tabular}


Lowland beech forest stands perform social, ecological, protective, and raw material supply (productive) functions (Myklush, 2011). The distribution of the stands' areas according to their ecological and socio-economic values and depending on their main functions in accordance with the Forest Code of Ukraine (Forest, 1994) shows that more than $51 \%$ of lands occupied by lowland beech stands belong to protective, recreation forests and forests of nature conservation, scientific, historical and cultural purposes (Table 2). 16 categories of protectiveness are distinguished among them according to their purpose.

According to the analyzed materials, $48.9 \%$ of the area of beech forests is classified as exploitable (commercial), and more than $27.8 \%$ of forest stands, based on the predominance of functions performed by them, are assigned to forests that have nature conservation, scientific, historical and cultural purposes, $21.2 \%$ of the stands' area belong to recreation forests.

Beech forests that perform protective functions are represented by ravine, anti-erosion forests and riparian forests along the banks of rivers and other bodies of water, rightof-ways. Their area is 2,522.5 hectares or $2.1 \%$ of the area of the lowland beech forest stands. The largest area is occupied by forests along rivers, around reservoirs (1.1\%), where almost one percent of the area falls on natural seed beech stands. Of great importance are ravine- $(0.3 \%)$ and anti-erosion $(0.1 \%)$ beech stands because they prevent soil erosion and soil ablation on the banks of gullies, ravines, river valleys. More than 200 ha of the ravine forests have been set aside for establishing beech forest plantations.

Recreation and aesthetically pleasing forests perform sanitary-hygienic, recreational and health-promotion functions. They are located within and outside cities and settlements, as well as within the districts of the sanitary protection of health-improving territories and resorts (Decree, 2007).

The greatest share of the area of these stands comes under forest management of the forests of green zones of settlements - 20.7 thousand hectares, of which almost $14.6 \%$ are represented by natural seed stands. More than 3 thousand hectares $(2.8 \%)$ of beech forests are attributed to the forest-park part of the green zone forests.

Beech stands of significant area are represented in the forests of nature conservation, scientific, historical and cultural purposes. The largest areas of these beech forest stands are attributed to landscape regional parks (10.6\%), national nature parks $(7.9 \%)$ and more than $6.9 \%$ to wildlife reserves, dominated by natural seed stands.

Protective and raw material supply functions (productive functions) are provided with exploitable (commercial) beech forests, of which almost $84 \%$ are represented by natural seed forest stands, and more than $15.5 \%$ - by artificial stands.

The lowland beech forest stands are characterized by different structures, they are inhomogeneous in origin and composition and perform numerous diverse functions. Each of the functions of beech forests under certain conditions is most important, but it is not the only one. The value of individual functions increases with the development of industrial production or climate change. Recently, detailed studies on the energy-, oxygen production, carbon sequestration functions have been conducted (Vasylyshyn, 2014; Lakyda, 2011; Myklush, 2011).

To ensure the sustained use of forest resources, it is necessary to provide, on a scientifically sound basis, formati- on and functioning of a mechanism for the sustainable development of forest ecosystems, their biological diversity, productivity, capacity for regeneration, viability and the ability to perform both now and in the future environmental, economic, social and other functions.

Researchers believe that in order to ensure the most complete performance by forests of their functions, it is necessary to elaborate methods of forest management that would form the stands which in their structure and composition conform to certain standards. The most thoroughly have been elaborated basic principles and guidelines for formation of the structure and growth of normal exploitable forests which are characterized by straight, full, clear trunk and provide the largest volumes of high quality wood (Krynytsky, et al., 2004; Myklush, 2011; Rules, 2009). It is obvious that the characteristics of normal stands, which perform primarily the raw material supply functions, will differ from the forest-inventory parameters, spatial structure and productivity of protective, nature-conservation or recreation forest stands. In each specific case, differentiated approaches to forest management, planning and implementation of silvicultural treatments are needed to form the structure of forest stands. This is evidenced by the forest-inventory indices of the most productive tree stands of different categories of protectiveness (Table 3).

The raw material supply function is determined by the growing stock. The most productive conditions for beech forests are fresh and moist fertile beech forest types, where highly productive tree stands are formed, regardless of the categories of protectiveness. The maximum growing stock $\left(600-620 \mathrm{~m}^{3} / \mathrm{ha}\right)$ is produced by the natural seed forests of site class $\mathrm{I}^{\mathrm{a}}$, while the existing beech plantations are characterized by $100 \mathrm{~m}^{3} /$ ha lower stocks, although they also grow in fresh oak-hornbeam beech forests, but are 20 years younger.

It is necessary also to take into account the fact that the defined functions of forest stands are most effectively performed under certain conditions such as age, c structure of stands, for example, the oxygen-production and carbon-sequestration functions are best fulfilled during the period of intensive growth, which is characteristic of middle-aged stands, but in this age period forest tracts are aesthetically less attractive than fully-stocked mature stands which more effectively provide a recreational function, etc. Protective function, which is performed by all beech forests, is the most effectively fulfilled by areas covered with forest vegetation. In view of the ability of beech stands to be well regenerated naturally, it is necessary to use gradual felling more extensively and to switch to selection management system in beech forests. The use of modern equipment and techniques makes it possible to use the exploitable volume of wood within the limits of ingrowth, competently selecting thick trunks and creating conditions for the emergence and development of advance growth, which will ensure the stability of forest ecosystems, increase the protective and conservational functions of forests, and reduce costs for reforestation. Depending on the location of the lowland beech forests, their economic, environmental and social significance, the main functions in certain regions may be different ones.

Lack of elaborated methodological approaches to economic evaluation of most forest functions does not diminish their significance, but requires a well-balanced approach to the use of diverse functions of forests, forest resources and biodiversity conservation. 
Table 3. Forest-inventory indices of the most productive beech stands of various origin

\begin{tabular}{|c|c|c|c|c|c|c|c|}
\hline \multirow{2}{*}{ Forest type index } & \multirow{2}{*}{$\begin{array}{l}\text { Age, } \\
\text { years }\end{array}$} & \multirow{2}{*}{ Composition } & \multicolumn{2}{|c|}{ Average } & \multirow{2}{*}{$\begin{array}{c}\text { Relative } \\
\text { density }\end{array}$} & \multirow{2}{*}{$\begin{array}{l}\text { Growth } \\
\text { class }\end{array}$} & \multirow{2}{*}{$\begin{array}{c}\text { Growing } \\
\text { stock, } \mathrm{m}^{3} / \mathrm{ha}\end{array}$} \\
\hline & & & height, $m$ & diameter, $\mathrm{cm}$ & & & \\
\hline \multicolumn{8}{|c|}{ Natural seed stands } \\
\hline \multicolumn{8}{|c|}{ Reserved isolated terrain feature } \\
\hline $\mathrm{D}_{2}$-OKHBMBE & 124 & $10 \mathrm{BE}+\mathrm{HBM}$ & 36.2 & 44.3 & 0.85 & $\mathrm{I}^{\mathrm{a}}$ & 620 \\
\hline \multicolumn{8}{|c|}{ Exploitable forests } \\
\hline $\mathrm{D}_{3^{-}} \mathrm{OKHBMBE}$ & 89 & $10 \mathrm{BE}+\mathrm{HBM}$ & 31.2 & 37.6 & 0.88 & $\mathrm{I}^{\mathrm{a}}$ & 611 \\
\hline \multicolumn{8}{|c|}{ Recreation forests } \\
\hline $\mathrm{D}_{3^{-}} \mathrm{OKHBMBE}$ & 124 & 10BE+HBM & 34.4 & 47.2 & 0.82 & $\mathrm{I}^{\mathrm{a}}$ & 616 \\
\hline \multicolumn{8}{|c|}{ Artificial seed stands } \\
\hline \multicolumn{8}{|c|}{ Bank-protection forests } \\
\hline $\mathrm{D}_{2^{-}} \mathrm{OKHBMBE}$ & 101 & $10 \mathrm{BE}+\mathrm{HBM}$ & 32.8 & 41.6 & 0.81 & $\mathrm{I}^{\mathrm{a}}$ & 519 \\
\hline \multicolumn{8}{|c|}{ Reserved forests } \\
\hline $\mathrm{D}_{2^{-}} \mathrm{OKHBMBE}$ & 104 & 9BE1HBM & 27.3 & 39.2 & 0.81 & $\mathrm{I}^{\mathrm{a}}$ & 500 \\
\hline \multicolumn{8}{|c|}{ Exploitable forests } \\
\hline $\mathrm{D}_{2}$-HBMOK & 62 & 9BE1HBM & 30.2 & 31.2 & 0.90 & $\mathrm{I}^{\mathrm{a}}$ & 467 \\
\hline \multicolumn{8}{|c|}{ Coppice forests } \\
\hline \multicolumn{8}{|c|}{ Reserved forests } \\
\hline $\mathrm{D}_{3^{-}} \mathrm{OKHBMBE}$ & 124 & $10 \mathrm{BE}+\mathrm{HBM}$ & 32.2 & 38.8 & 0.71 & $\mathrm{I}$ & 453 \\
\hline \multicolumn{8}{|c|}{ Exploitable forests } \\
\hline $\mathrm{D}_{3^{-}} \mathrm{OKHBMBE}$ & 117 & 8BE2HBM & 29.7 & 46.1 & 0.74 & $\mathrm{I}$ & 440 \\
\hline \multicolumn{8}{|c|}{ Recreation forests } \\
\hline $\mathrm{D}_{3}-\mathrm{OKHBMBE}$ & 125 & 9Бк1Г 9ВЕ1НВM & 31.4 & 49.2 & 0.73 & $\mathrm{I}$ & 422 \\
\hline
\end{tabular}

\section{Conclusions}

The area of the lowland forest stands with the participation of European beech is 216,113.4 hectares, and with the predominance of beech in the composition of stands 118,902.9 hectares (as of 1 January 1996 - 104.8 thousand hectares). Among the beech forest stands prevailing are natural seed forest stands with an area of $85.7 \%$ of the lowland beech stands. The area of natural stands, where beech prevails in the composition, is almost 102 thousand hectares, and the area of artificial stands with predominance of European beech is over 16.5 thousand hectares.

The lowland beech stands are medium-stocked, their site class is $\mathrm{I}^{\mathrm{a}}, 5$, they are assigned to 16 categories of protectiveness.

Taking into account the important ecological, protective, conservation, social value of beech forests, the need of the country's economy in high-quality merchantable beech wood, it is necessary, on the basis of modern equipment and technology, to move to a selection system of forest management using the volume of mature wood within the limits of ingrowth, competently selecting thick trunks and creating conditions for the emergence and development of advance growth, which will ensure the stability of forest ecosystems, increase the protective and conservation functions of forests, and reduce costs for reforestation.

The practical implementation of the provisions for the multi-purpose use of forest resources should be based on the principles of sustainable development, and the design and implementation of forestry activities should not violate the principles of close-to-nature forest management.

\section{References}

Decree. (2007). Decree of the Cabinet of Ministers of Ukraine No., 733 dated May 16, 2007 "On Approval of the Procedure for the Division of Forests into Categories and Identification of Highly Protective Forest Areas". Retrieved from: http://zakon2.rada.gov.ua/laws/show/733-2007-\%D0 \%BF. [in Ukrainian].

Directory. (2016). Directory of Forest Fund of Ukraine on the materials of state registration of forests as of January 1. Voronezh State Enterprise "Ukrderzhlisproekt". Irpin: State Forest Resources Agency of Ukraine, $130 \mathrm{p}$. [in Ukrainian].

Forest. (1994). Forest Code of Ukraine. Retrieved from: http://zakon1.rada.gov.ua/laws/show/3852-12/page. [in Ukrainian].

Krynytsky, G. T., Popadynets, I. M., Bondarenko, V. D., \& Kramarets, V. O. (2004). Beech forests of the Western Podillya. Ternopil: Ukrmedkniga, 168 p. [in Ukrainian].

Lakyda, P. I., Bilous, A. M., Vasylyshyn, R. D., \& Matushevych, L. M. (2011). Estimation of energy content in the phytomass of the Ukrainian Polissya soft-wooded broadleaved species. Scientific works of the Forestry Academy of Sciences of Ukraine: collection of scientific works, 9, 121-124. Lviv: RVV UNFU. [in Ukrainian].

Molotkov, P. I. (1972). Beech forests of the Ukrainian Carpathians. Beech Forests of the USSR and their management (pp. 78-109). Moscow: Forest Industry. [in Russian].

Myklush, S. I. (2011). Lowland Beech Forests in Ukraine: Productivity and Organization of Sustainable Management: Monograph. Lviv: ZUCTS, 260 p. [in Ukrainian].

Rules. (2009). The rules for final cutting in the forests of Ukraine. Kyiv, 12 p. [in Ukrainian].

State. (2015). State Forest Resources Agency. Retrieved from: http://dklg.kmu.gov.ua/forest/control/uk/index. [in Ukrainian].

Vasylyshyn, R. D. (2014). Productivity and ecological energy potential of forests in the Ukrainian Carpathians. Abstract of doctoral dissertation for Agricultural Science (06.03.02 - Forest management and forest inventory). Kyiv, 46 p. [in Ukrainian].

С. І. Миклуші, Ю. С. Миклуші, В. М. Савчин ${ }^{2}$

${ }^{1}$ Національний лісотехнічний університет України, м. Львів, Украӥна

${ }^{2}$ Виробниче об'єднання "Укрдержліспроект", м. Львів, Україна

\section{СТРУКТУРА ЛІСОВОГО ФОНДУ І ФУНКЦІЇ РІВНИННИХ БУКОВИХ ЛІСІВ УКРАЇНИ}

За матеріалами лісовпорядкування станом на 01.01.2015 р. проаналізовано лісівничо-таксаційні показники лісостанів за участі бука у складі, що ростуть в умовах рівнинної частині України. Площа рівнинних лісостанів 3 участю бука лісового у складі становить 216113,4 га (загальна кількість ділянок - 47231), а лісостанів 3 переважанням бука у складі - 118902,9 га 
(станом на 01.01.1996 р. - 104,8 тис. га). Встановлено, що в рівнинних умовах переважають природні насіннєві насадження. Площа природних насаджень, де бук переважає у складі - майже 102 тис. га, а площа штучно створених насаджень 3 переважанням бука лісового - понад 16,5 тис. га. На відміну від природних насіннєвих насаджень, лісові культури чи вегетативні насадження формуються 3 незначною часткою бука у складі. Насадження з участю бука лісового формуються, переважно, у свіжих (понад 44 \%) та вологих (83,4 \%) грудах. Чисті букові лісостани ростуть на 8,6 \% площ. Найбільше (10,3\%) 3 них мають природне насіннєве походження. Серед досліджуваних лісостанів майже 12,5 \% займають ділянки, на яких трапляються поодинокі дерева бука лісового із запасом менше $5 \%$, а за площею переважають середньовікові - 36,9\% та пристиглі27,1 \%. У природних насадженнях незначні (6,8 \%) площі зайняті молодняками. Насіннєві букові насадження як природного, так і штучного походження характеризуються однаковим середнім класом бонітету - $1{ }^{\text {a }}, 5$, а понад $36 \%$ площ букових лісостанів, незалежно від походження, мають відносну повноту 0,7. Понад 51 \% площ рівнинних букових насаджень належать до захисних, рекреаційно-оздоровчих лісів та лісів природоохоронного, наукового, історико-культурного призначення. Серед рекреаційно-оздоровчих лісів найбільша частка площ припадає на лісогосподарську частину лісів зелених зон населених пунктів - 20,7 тис. га, 3 яких майже 14,6 \% представлені природними насіннєвими насадженнями. Понад 3 тис. га $(2,8 \%)$ букових лісів віднесено до лісопаркової частини лісів зелених зон. Зазначено, що інтенсивні лісогосподарські заходи у середньовікових і пристигаючих деревостанах істотно знижують їх відносну повноту і запаси. За перевагою виконуваних лісостанами функцій виділено 16 категорій захисності. Для формування високопродуктивних букових деревостанів $\mathrm{i}$ використання лісових ресурсів потрібно здійснювати перехід до вибіркової форми господарства.

Ключові слова: бук лісовий (Fagus sylvatica L.); рівнинні насадження; матеріали лісовпорядкування; лісівничо-таксаційні показники; продуктивність; функції.

С. И. Миклуші, Ю. С. Миклуш', В. М. Савчин ${ }^{2}$

${ }^{1}$ Национальный лесотехнический университет Украины, г. Львов, Украина

2 Производственное объединение "Укргосплеспроект", г. Львов, Украина

\section{СТРУКТУРА ЛЕСНОГО ФОНДА И ФУНКЦИИ РАВНИННЫХ БУКОВЫХ ЛЕСОВ УКРАИНЫ}

По материалам лесоустройства древостоев с участием бука лесного в составе произрастающих в условиях равнинной части Украины по состоянию на 01.01.2015 г. проанализированы их лесоводственно-таксационные показатели и основные функции, которые выполняют буковые насаждения. Площадь древостоев с участием бука лесного в составе равна 216113,4 га (общее количество участков - 47231), а древостоев с преобладанием бука в составе - 118902,9 га (по состоянию на 01.01.1996 г. - 104,8 тыс. га). Установлено, что в равнинных условиях преобладают естественные семенные насаждения. Насаждения с участием бука формируются преимущественно в свежих (более 44 \%) и влажных $(39,4 \%)$ грудах. Чистые буковые насаждения растут на 8,6\% площадей. Среди исследуемых древостоев по площади преобладают средневозрастные $36,9 \%$ и приспевающие древостои - 27,1\%. Семенные буковые насаждения как естественного, так и искусственного происхождения характеризуются одинаковым средним классом бонитета - 1a,5, а более 36 \% площадей буковых древостоев, независимо от их происхождения, характеризуется относительной полнотой 0,7 . Более $51 \%$ площадей равнинных буковых насаждений относятся к защитным, рекреационно-оздоровительным лесам и лесам природоохранного, научного, историкокультурного назначения. Среди рекреационно-оздоровительных лесов наибольшая ее долевое участие площадей приходится на лесохозяйственную часть лесов зеленых зон населенных пунктов - 20,7 тыс. га, из которых почти 14,6 \% представлены естественными семенными насаждениями. Более 3 тыс. га $(2,8 \%)$ буковых лесов отнесены к лесопарковой части лесов зеленых зон. Отмечено, что интенсивные лесохозяйственные мероприятия в средневозрастных и приспевающих древостоях существенно снижают их относительную полноту и запасы древесины. По преимуществу выполняемых древостоями функций выделено 16 категорий защитности. Для формирования высокопродуктивных буковых древостоев и использования лесных ресурсов необходимо осуществлять переход к выборочной форме хозяйства.

Ключевые слова: бук лесной (Fagus sylvatica L.); равнинные насаждения; материалы лесоустройства; лесоводственнотаксационные показатели; производительность, функции. 